\title{
Do MHCII-Presented Neoantigens Drive Type 1 Diabetes and Other Autoimmune Diseases?
}

\author{
Philippa Marrack ${ }^{1,2}$ and John W. Kappler ${ }^{1,3}$ \\ ${ }^{1}$ Howard Hughes Medical Institute and Integrated Department of Immunology, National Jewish Health, \\ University of Colorado Denver, School of Medicine, Denver, Colorado 80206 \\ ${ }^{2}$ Department of Biochemistry and Molecular Genetics, University of Colorado Denver, School of Medicine, \\ Aurora, Colorado 80045 \\ ${ }^{3}$ Program in Structural Biology and Biophysics, University of Colorado Denver, School of Medicine, Aurora, \\ Colorado 80045 \\ Correspondence: kapplerj@njhealth.org
}

\begin{abstract}
The strong association between particular MHCII alleles and type 1 diabetes is not fully understood. Two ideas that have been considered for many years are that autoimmunity is driven by (1) low-affinity $\mathrm{CD}^{+}{ }^{+} \mathrm{T}$ cells that escape thymic negative selection and respond to certain autoantigen peptides that are particularly well presented by particular $\mathrm{MHCll}$ molecules, or (2) $\mathrm{CD}^{+} \mathrm{T}$ cells responding to neoantigens that are absent in the thymus, but uniquely created in the target tissue in the periphery and presented by particular MHCII alleles. Here we discuss the recent structural data in favor of the second idea. We review studies suggesting that peptide antigens recognized by autoimmune $\mathrm{T}$ cells are uniquely proteolytically processed and/or posttranslationally modified in the target tissue, thus allowing these T cells to escape deletion in the thymus during T-cell development. We postulate that an encounter with these tissue-specific neoantigenic peptides presented by the particular susceptible $\mathrm{MHCll}$ alleles in the peripheral tissues when accompanied by the appropriate inflammatory milieu activates these T-cell escapees leading to the onset of autoimmune disease.
\end{abstract}

$\mathrm{T}_{\mathrm{t}}^{\mathrm{h}}$ he nature of self versus nonself discrimination has fascinated and frustrated immunologists for more than a century. How can the adaptive immune response produce receptors that can recognize virtually any chemical moiety present in nature or dreamt up in the chemist's laboratory, but peacefully coexist with the tens of thousands of potential antigens present in its host, a state referred to as "self-tolerance?" This is a crucial issue because, if the immune system is not tolerant to its host, it can attack and destroy host tissues causing autoimmune diseases such as type 1 diabetes (T1D).

Experiments over the last $60-70$ years have revealed that self-tolerance is affected in many ways. Of these processes, the first to be unequivocally demonstrated was the fact that, for both $\mathrm{B}$ and $\mathrm{T}$ cells, their immature precursors are checked during development for potential reaction to self. In a process known as "negative selection," immature lymphocytes are eliminated either by enforced death (Kappler et al. 1987;

Editors: Jeffrey A. Bluestone, Mark A. Atkinson, and Peter Arvan

Additional Perspectives on Type 1 Diabetes available at www.perspectivesinmedicine.org

Copyright (C) 2012 Cold Spring Harbor Laboratory Press; all rights reserved; doi: 10.1101/cshperspect.a007765

Cite this article as Cold Spring Harb Perspect Med 2012;2:a007765 
Kisielow et al. 1988; Hartley et al. 1991) or by new rearrangements of their antigen receptor genes such that their autoreactive receptor is "edited" by replacement with a new receptor (Gay et al. 1993; McGargill et al. 2000).

Deletion and receptor editing of immature autoreactive precursors are not the only processes that affect self-tolerance. Additional layers of protection have been discovered that deal with self-reactive lymphocytes that escape developmental negative selection. Although both the B-cell and T-cell branches of the adaptive immune response must deal with these self-reactive escapees, in this article we will discuss negative selection and these postdevelopment safeguards with respect to $\mathrm{T}$ cells, particularly $\mathrm{CD} 4^{+} \mathrm{T}$ cells, because these seem to be central to the pathology of many autoimmune diseases.

After the demonstration of thymic elimination of many immature autoreactive $\mathrm{T}$ cells, it quickly became obvious that some self-reactive T cells slip through this filter and must be held in check in the periphery. Numerous reinforcing mechanisms have been discovered that serve this purpose. Some involve coreceptors on mature $\mathrm{T}$ cells that must synergize with the T-cell receptor (TCR) to promote optimal activation, expansion, and/or differentiation, whereas other receptors on $\mathrm{T}$ cells act negatively to curtail the T-cell response or even kill the responding $\mathrm{T}$ cell (Tivol et al. 1996; Chambers and Allison 1997; Greenwald et al. 2005).

Dead cells could be a source of self-antigens that might stimulate autoimmune attack. To circumvent this problem, many processes have evolved that allow rapid clearance of dead cells with concomitant production of immunosuppressive cytokines, thus lessening the chance of effective presentation of self-antigens from these cells (Erwig and Henson 2008).

One postthymic safeguard system that has been extensively studied in recent years involves a heterogeneous group of specialized $\mathrm{CD} 4^{+} \mathrm{T}$ cells called regulatory $\mathrm{T}$ cells (Tregs) (reviewed in Sakaguchi 2006; Josefowicz and Rudensky 2009; Shevach 2009; Klein and Jovanovic 2011; Shalev et al. 2011; Wirnsberger et al. 2011). Although there is still much about these cells that we do not understand, most of them appear to be specific for self-antigens. However, rather than attacking the host, they operate by suppressing the response of other potentially harmful self-reactive $\mathrm{T}$ cells. These anti-self-protective T cells appear to be a by-product of thymic development. Some studies suggest that their differentiation in the thymus is driven by lowaffinity interactions with self-antigens that are too weak to induce negative selection.

All of these intrinsic and extrinsic mechanisms appear to be essential for the maintenance of T-cell self-tolerance, because natural or experimental disruption of any of them leads to generalized autoimmunity. However, most cases of spontaneous autoimmunity in humans and other animals do not seem to be caused by a general failure in any of these pathways, or, for that matter, a general failure in the mechanism of thymic negative selection. Therefore, although the study of these thymic and extra-thymic mechanisms of controlling self-reactive $\mathrm{T}$ cells has taught us much about how self-tolerance is established and maintained in normal individuals, it has not shed light on an important remaining question: How do autoreactive $\mathrm{T}$ cells usually escape thymic negative selection and slip through all of the postthymic safeguards to become the fully activated effectors of autoimmunity?

In the rest of this work we will explore a hypothesis that might be the answer to this question. Mature $\mathrm{T}$ cells must be able to respond productively to foreign antigens such as those present on infectious agents. The T cells in these responses exist and respond not only because their antigen is absent in the thymus to effect negative selection, but also because the various peripheral mechanisms for limiting T-cell responses are relaxed in the response to foreign antigens, primarily through modulation by inflammatory signals coming from the innate immune system, called into play by molecular signals released by tissue injury or invading organisms. These signals activate the toll-like receptors or other intracellular danger-signaling pathways leading to the up-regulation of receptors in antigen-presenting cells (APCs) for the stimulatory coreceptors on T cells. Inflammatory cytokines and chemokines also directly 
influence the fate of naïve T cells whose TCR has been engaged and modulate the activity of regulatory T cells. Based on recent studies detailing the structural nature of a number of antigens driving $\mathrm{CD} 4{ }^{+} \mathrm{T}$-cell-mediated autoimmune diseases, such as type 1 diabetes (T1D), we propose that the antigens initiating these diseases may be more akin to foreign antigens than self-antigens, enabling these T cells to slip through the filters designed to eliminate them or limit their activity.

\section{CONVENTIONAL PEPTIDE PROCESSING AND PRESENTATION BY MHCII TO CD4 ${ }^{+}$T CELLS}

$\mathrm{CD}^{+}{ }^{+} \mathrm{T}$-cell recognition of a protein antigen, whether foreign or self, requires processing of the protein into peptides and presentation of the correct peptides bound properly in the groove of an MHCII molecule. Since the early 1980s, the nature of this pathway has been worked out in considerable detail (Fig. 1) (Shimonkevitz et al. 1984; Jensen et al. 1999; Nakagawa and Rudensky 1999; Zhou and Blum 2004; Busch et al. 2005; Trombetta and Mellman 2005).

Antigen is most effectively presented to naïve $\mathrm{T}$ cells by APCs that have special pathways for taking up extracellular protein antigens or intrinsic proteins from the secretory pathway, degrading them to peptides and loading the peptides into MHCII molecules in specialized endosomal compartments. The degradation step is generally performed by a series of endosomal/ lysosomal enzymes, such as disulfide reductases and proteolyic cathepsins. Nascent MHCII molecules in complex with the invariant chain chaperone (Ii) can enter these somewhat acidic endosomes and, under the catalytic influence of resident MHCII-like molecules (DM and DO), a fragment of the degraded Ii chain (CLIP) is removed from the MHCII groove and replaced with a compatible endosomal peptide. The MHCII-peptide complex then traffics to the cell surface for potential recognition by $\mathrm{CD} 4^{+} \mathrm{T}$ cells (Fig. 1A).

Although this is the major way in which MHCII-peptide complexes are formed, there are other pathways as well. APCs can also pull
The Importance of Neoantigens in Autoimmunity

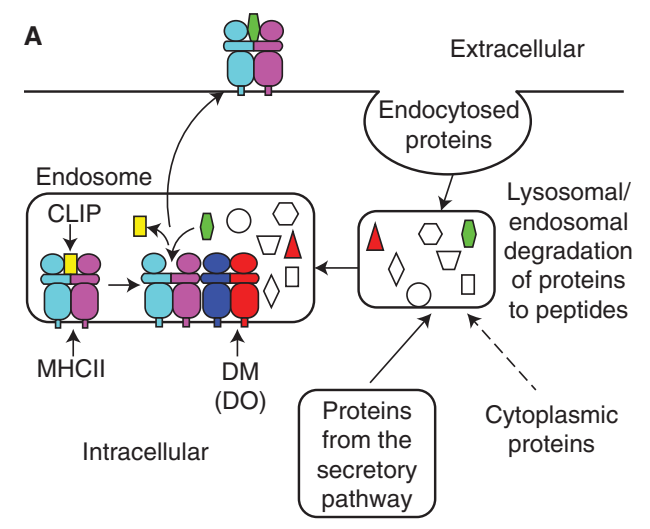

B

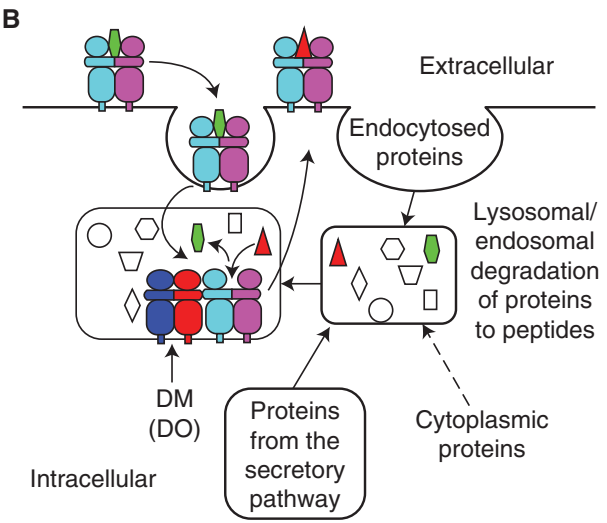

C

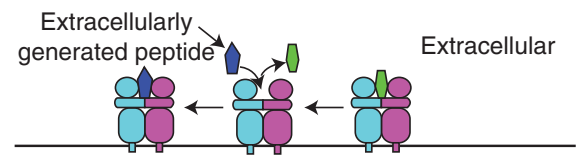

Figure 1. Schematic diagram of the various sources of peptides and the three main ways they are loaded into MHCII. (A) The major pathway involves newly synthesized MHCII trafficking to the endosomes from the Golgi complexed to invariant chain. After degradation of the invariant chain, DM/DO facilitates exchange of the residual invariant chain CLIP peptide for endosomally generated peptides. In the competition for binding among the peptides, those (colored) that best match the MHCII allelic binding motif are favored. The sources of these peptides are mostly proteins diverted from the secretory pathway or endocytosed from the cell membrane or extracellular cellular fluid, but in some antigen-presenting cells cytoplasmic proteins can enter this endosomal pathway. (B) Recycled cell-surface MHCII can reenter the endosome pathway and exchange its original peptide for a new internally generated one. $(C)$ At the cell surface MHCII can lose its original peptide and take up one generated extracellularly. 
cytoplasmic proteins into this endosomal compartment through the process of autophagy (Nimmerjahn et al. 2003). An MHCII-peptide complex on the cell surface can be internalized and recycled through the endosomal pathway, exchanging its peptide for a new one (Fig. 1B) (Walseng et al. 2008). Finally, this type of peptide exchange can happen on the cell surface with peptides generated extracellularly (Fig. 1C) (Shimonkevitz et al. 1984). Important for autoimmunity, this means that tissue-specific peptides that are not generated by the internal APC protein-processing machinery can nevertheless be presented to $\mathrm{CD} 4^{+} \mathrm{T}$ cells.

The structural basis of peptide binding to MHCII is now well understood (Jones 1997; McFarland and Beeson 2002). Peptides bind in the grooves of MHCII molecules in an extended polyproline-like helix forming a series of conserved hydrogen bonds ( $\mathrm{H}$ bonds) between MHCII amino acids and the peptide backbone (Fig. 2A). These $\mathrm{H}$ bonds stabilize the bound peptide in a particular position or "register" in the groove, while the ends of the peptide are free to hang out of either end. For each shift in binding register in the groove, the helical peptide must not only shift by exactly one amino acid, but also rotate by about 130 degrees to maintain the critical $\mathrm{H}$ bonds. Thus, each shift in register results in bringing a new set of peptide amino acid side chains to the surface of MHCII creating an entirely new ligand for T-cell recognition. In any register, the nine amino acids that fill the center of the binding groove are numbered $\mathrm{N}$ - to C-terminally, $\mathrm{p} 1$ to $\mathrm{p} 9$. Peptide amino acids prior to $\mathrm{p} 1$ are numbered $\mathrm{p}-1$, p-2, etc. (Fig. 2A,B).

Because the $\mathrm{H}$ bonds are to the peptide backbone, not its side chains, any peptide might bind in any register to any MHCII protein. However, this is not possible because the MHCII groove has four pockets, into which the p1, p4, p6, and p9 amino acid side chains of the peptide must fit (Fig. 2B-D). For any given MHCII molecule, the types of the MHCII amino acids that line each pocket limit the peptide amino acids that are allowed to occupy that pocket, thus controlling which peptides can bind and limiting the allowed binding registers.
A good match between an MHCII pocket and a peptide amino acid side chain can enhance peptide binding. Most pockets accept several different amino acids, but an overt steric or chemical clash can inhibit or even prevent binding. Short side chains that fail to fill the pocket are generally allowed. Most importantly, the majority of polymorphisms in MHCII alleles are concentrated in the amino acids that form the four pockets in the MHCII peptide-binding groove, so that in different MHCII alleles these pockets often have different sizes, shapes, and chemistries. Thus, each MHCII allele has a particular peptide binding "motif," limiting both the spectrum of peptides that can bind and the possible binding registers for each peptide.

In normal unimmunized individuals the grooves of MHCII molecules are filled almost entirely with peptides derived from degraded self-proteins. Mass spectrometric analysis of these peptides indicates that at least hundreds, and perhaps thousands, of different self-peptides occupy the grooves of each particular MHCII allele expressed on the cell surface of an APC (Lippolis et al. 2002). Thus, $\mathrm{CD} 4^{+} \mathrm{T}$ cells are exposed to a plethora of potential self-ligands both during development and in the periphery. This continuous exposure to self-antigen drives the process of thymic negative selection and plays a role in a number of the peripheral mechanisms that control autoreactive $\mathrm{T}$ cells.

To ensure that even those self-proteins that are otherwise unique to particular organs are present and processed in the thymus during development, the AIRE transcription factor, expressed in thymic $\mathrm{MHCII}^{+}$medullary epithelium, causes expression of a number of peripheral tissue-specific proteins in $\mathrm{MHCII}^{+}$thymic stromal cells (Mathis and Benoist 2007). AIRE expression in a subpopulation of peripheral APCs, may also contribute to peripheral control of selfreactive T cells (Metzger and Anderson 2011). The importance of AIRE is dramatically shown by the multiorgan autoimmunity that develops in humans and mice that lack its function.

During an active immunization with a foreign antigen, foreign proteins enter the pathway for loading peptides into MHCII and their peptides compete with those from self-proteins for 
The Importance of Neoantigens in Autoimmunity

A MHCII conserved H-bond network to
peptide backbone
C

MHCIl pockets accepting $\mathrm{p} 1, \mathrm{p} 4$, $\mathrm{p} 6$, and $\mathrm{p} 9$ side chains $\left(\mathrm{IE}^{\mathrm{k}}-\mathrm{pHb}\right)$

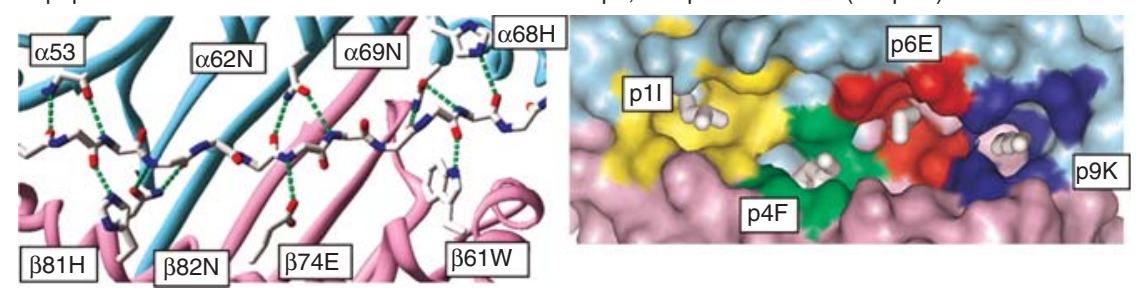

B Numbering convention for $\mathrm{MHCll}$ bound peptides (IE $\left.{ }^{\mathrm{k}}-\mathrm{pHb}\right)$

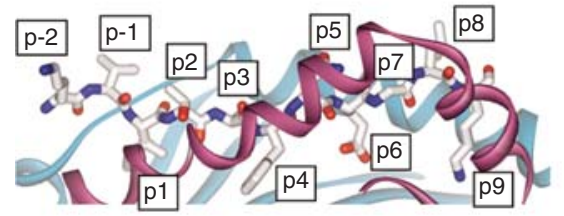

D Degenerate specificities of $\mathrm{p} 1, \mathrm{p} 4, \mathrm{p} 6$, and $\mathrm{p} 9$ pockets $\left(\mathrm{IE}^{\mathrm{k}}\right)$

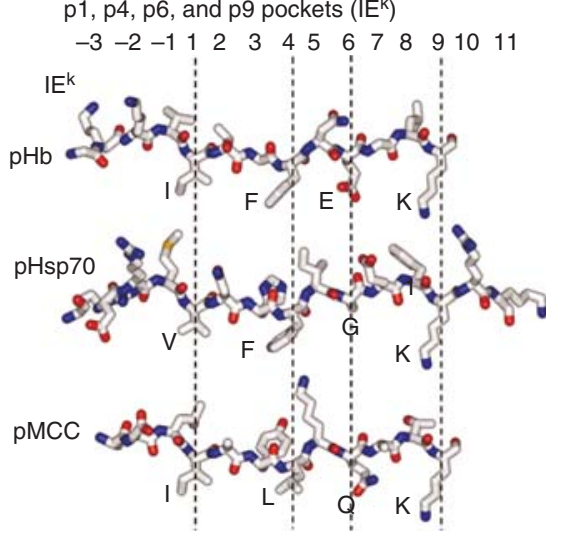

E Conventional TCR interactions with self and foreign peptides bound to MHCII

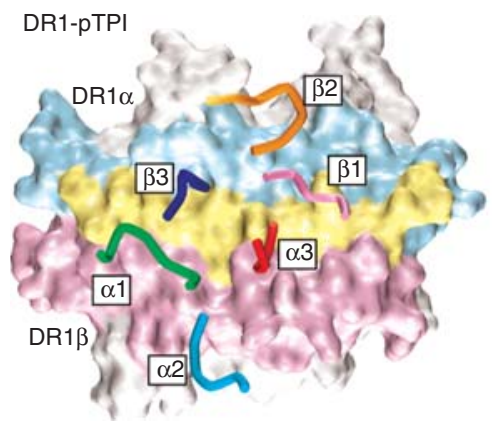

IA - -p3K

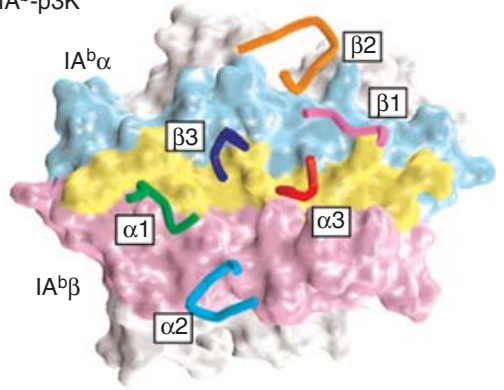

Figure 2. Conventional peptide-MHCII presentation and recognition by $\mathrm{CD} 4^{+}$T-cell TCRs. $(A)$ The conserved $\mathrm{H}$-bonding network between MHCII amino acids and the bound peptide hold the peptide in a polyproline-like extended helix. The eight MHCII amino acids involved in the network are conserved among MHCII isotypes and alleles in all species. $(B)$ The numbering scheme used for MHCII-bound peptides. $(C)$ Using the mouse MHCII molecule $\mathrm{IE}^{\mathrm{k}}$ as an example, the pockets in the peptide-binding groove that accept the side chains of the p1 (yellow), p4 (green), p6 (red), and p9 (blue) amino acids of the peptide are shown occupied by amino acids from a self-peptide from hemoglobin ( $\mathrm{pHb}$ ) (PDB 1IEA). (D) The structures of two self-peptides, $\mathrm{pHb}$ and a peptide from heat shock protein 70 ( $\mathrm{pHsp} 70$ ) (PDB 1IEB), and one foreign peptide from moth cytochrome $\mathrm{c}$, pMCC (PDB 1KT2), are shown when bound to $\mathrm{IE}^{\mathrm{k}}$, demonstrating the degeneracy allowed by the IE $\mathrm{F}^{\mathrm{k}} \mathrm{p}$-, $\mathrm{p} 4-$, p6-, and p9-binding pockets. (E) The conventional positions of TCR CDR loops are shown on surfaces of two MHCII-peptide ligands: a self-peptide from mutated triose phosphate isomerase (pTPI) bound to human HLA-DR1 and a foreign synthetic peptide, $\mathrm{p} 3 \mathrm{~K}$, bound to mouse $\mathrm{IA}^{\mathrm{b}}$. The tube representations of the CDR loops are colored as follows: $\mathrm{V} \alpha \mathrm{CDR} 1$, green; CDR2, cyan; CDR3, blue; V CDR1, magenta; CDR2, orange; CDR3, red. The surfaces are colored as follows: MHCII strands, white; $\alpha$ helix of MHCII $\alpha$, light cyan; $\alpha$ helix of MHCII, light magenta; peptide, yellow. 
occupancy of the MHCII grooves. Over the past 20 years, a very large list of both foreign and selfpeptides have been identified that bind to particular MHCII alleles, compiled in databases such as SYFPEITHI (Rammensee et al. 1999). Likewise, there are many structures of these peptide-MHCII complexes. These data indicate that, in most cases, nothing distinguishes the binding of most self-peptides from that of foreign peptide. In either case the peptide usually fills the MHCII groove protruding from both ends and compatible peptide side chains fill the MHCII allele-specific pockets in the groove.

There are now also many solved structures of TCRs bound to MHCII carrying peptides derived from foreign or self-proteins (Fig. 2E) (Rudolph et al. 2006; Marrack et al. 2008). Although there is considerable flexibility allowed in the interface between TCRs and their ligands, some general rules of engagement have emerged. T-cell receptors use the amino acids in six loops, named TCR $\alpha$ CDR1-3 and TCR $\beta$ CDR1-3, to bind their MHC plus peptide ligands. In nearly all cases examined so far the TCR face containing the CDR loops sits diagonally across the MHCII helices. The highly variable CDR3 loops usually interact strongly with the bound peptide, with the V $\beta$ CDR2 loop poised over the MHCII $\alpha 1$ helix and the V $\alpha$ CDR2 loop over the MHCII $\alpha 1$ helix. The CDR1 loops of both $\mathrm{V} \alpha$ and $\mathrm{V} \beta$ often contact both peptide and MHCII. However, there are some striking exceptions to these rules that manifest in the autoimmunity settings highlighted below.

\section{WHY ARE MANY AUTOIMMUNE DISEASES STRONGLY ASSOCIATED WITH MHCII POLYMORPHISMS?}

The strong connection between MHCII polymorphisms and the risk of specific autoimmunity is now established in many diseases, including T1D, rheumatoid arthritis (RA), and multiple sclerosis (MS) (Shiina et al. 2004; Michels and Eisenbarth 2010; Stadinski et al. 2010a). This linkage is generally much stronger than that for any other genetic risk factor. Most often different autoimmune diseases are associated with different MHCII polymorphisms, but there are some overlaps. A priori, these findings suggest that it is some allele-specific feature of the presentation of particular tissue-specific autoantigens by MHCII, rather than a breakdown in any of the general mechanisms of self-tolerance, that creates the primary risk of autoimmunity. From this starting point, two almost diametrically opposed ideas have emerged to explain MHCII allele-specific autoimmunity.

The longest standing idea has been that, because most self- and foreign peptides appear to obey similar rules in binding to MHCII, tissuespecific autoimmunity is driven by self-peptides that bind particularly well to a particular MHCII allele, increasing the risk of triggering a low-affinity self-reactive $\mathrm{CD} 4^{+} \mathrm{T}$ cell that has escaped negative selection. Based on this idea, the sequences of the potential protein targets for $\mathrm{CD} 4{ }^{+} \mathrm{T}$ cells in these diseases were scanned for peptides containing signature sequence "motifs" that favor binding to the MHCII alleles associated with the disease, rather than to other MHCII alleles. A number of peptides were identified in this way. Binding and structural studies confirmed the ability of these peptides to occupy the grooves of the appropriate MHCII alleles in the predicted register (Hammer et al. 1995; Dessen et al. 1997; Lee et al. 2001; Patil et al. 2001; Wucherpfennig 2003). In some cases, $\mathrm{CD}^{+}{ }^{+} \mathrm{T}$ cells could even be found in humans or produced in immunized mice that recognized these complexes. However, evidence that these peptide-MHCII complexes are the ones initiating or driving autoimmune diseases in vivo has been much harder to obtain. Particularly disappointing has been the fact that, very often, $\mathrm{CD} 4^{+} \mathrm{T}$ cells isolated from the blood or affected tissues of naturally autoimmune patients or mice fail to bind fluorescent multimeric reagents consisting of soluble MHCII molecules loaded uniformly with one of these peptides (Kotzin et al. 2000). These types of reagents should detect such cells, because they routinely identify antigen-specific $\mathrm{CD} 4^{+} \mathrm{T}$ cells in the blood or lymphoid organs of humans or mice responding to foreign antigens (Crawford et al. 1998) or MHC transgenic mice deliberately immunized with the same self-peptide (Falta et al. 2005). 
These results raised the possibility that the $\mathrm{CD} 4^{+} \mathrm{T}$-cell targets of autoimmunity may often not be peptides produced by conventional processing of self-proteins or selected for optimal MHCII binding by competition with other peptides in the peptide loading endosomes. This has led us, and others, to consider various versions of an alternate idea as detailed below (Bankovich et al. 2004; Wucherpfennig et al. 2009; Stadinski et al. 2010a,b,c; Crawford et al. 2011). Perhaps the peptides targeted by autoimmune $\mathrm{T}$ cells are not produced by conventional endosomal protein processing, but are uniquely generated as neoantigens in the target tissue by other means and are a poor match to the binding motif of the relevant MHCII molecule.

This hypothesis not only explains the apparent failures to find autoimmune targets among the previous candidate peptides, but also provides a new rationale for autoimmunity and has suggested new experimental approaches to the problem. Because these tissue-specific peptides are uniquely generated in the periphery, they would be poorly presented in the thymus. $\mathrm{CD} 4^{+} \mathrm{T}$ cells bearing TCRs with a normal range of affinities for these peptides would therefore escape negative selection and need not be the low-affinity survivors of thymic negative selection. These $\mathrm{T}$ cells would first encounter the peptides in the peripheral tissue as a "neopeptide," akin to a foreign peptide, but perhaps poorly presented except in the target tissues where their levels are highest. Of course, to be functional in the periphery, these cells must also circumvent the many mechanisms of peripheral tolerance. However, as noted above, concomitant infection and/or bystander inflammation may allow such evasion. Perhaps this is why onset of so many autoimmune diseases is associated with various infections.

These ideas change the focus about the initiation of autoimmunity from notions of failure in the processes that govern thymus deletion and normal periphery tolerance to self to the question of how these tissue-specific peptides are generated in the periphery and how and in what context they are presented in a way that leads to productive activation of $\mathrm{CD} 4^{+} \mathrm{T}$ cells. It also offers a straightforward explanation for
The Importance of Neoantigens in Autoimmunity

why the risk of different autoimmune disease is linked to different MHCII alleles. Rather than the whole world of MHCII-bound self-peptides being potential initiators of autoimmunity, only this small number of specially generated peptides are relevant and each, like individual conventional foreign peptide epitopes, would be expected to be presented by a limited number of different MHCII alleles.

The best evidence for these types of neoantigens comes from recent experiments that have defined the molecular details of the MHCIIpeptide complexes targeted by autoreactive T cells. As discussed above many tissue-specific self-proteins have been suggested to be potential sources of target peptides for $\mathrm{CD} 4^{+} \mathrm{T}$ cells in a variety of autoimmune diseases. Some of the best candidates were initially identified by the presence of autoantibodies reactive to these proteins in autoimmune diseases. Others became candidates because deliberate immunization with these proteins induced autoimmunity in animal models. Sometimes the important $\mathrm{CD} 4^{+}$epitope has been traced to a particular region of the protein. However, it has only been recently that in a few cases, the nature of the peptide-MHCII complex recognized by pathogenic $\mathrm{CD} 4^{+} \mathrm{T}$ cells has been discovered. These data suggest that the critical peptide for $\mathrm{CD} 4^{+}$ $\mathrm{T}$ cells is often a tissue-specific neoantigen created by tissue-specific peptide processing or specific posttranslational modification. Although these ideas have been around for some time, the newer data now give a molecular reality to the hypothesis that these mechanisms play a direct role in $\mathrm{CD}^{+}{ }^{+} \mathrm{T}$-cell autoantigen creation.

\section{AUTOANTIGENS CREATED UNCONVENTIONAL PEPTIDE PROCESSING AND PRESENTATION IN THE TARGET TISSUE}

The best examples of autoimmune MHC-peptide complexes that indicate unusual tissue-specific processing, presentation, and/or recognition of the self-peptide bound to MHCII come from studies of human MS and T1D and of the mouse models of these diseases. In MS and its mouse model, experimental autoimmune encephalomyelitis (EAE), myelin basic protein 
P. Marrack and J.W. Kappler

(MBP) has been shown to be a major target of the $\mathrm{CD} 4{ }^{+} \mathrm{T}$ cells that cause a relapsing-remitting disease with eventual destruction of the myelin sheath of nerve fibers in the central nervous system. In both humans and mice numerous pathogenic $\mathrm{CD} 4^{+}$T-cell clones have been isolated and well characterized. The MBP peptides that are recognized by these $\mathrm{T}$ cells have been identified and their binding to the relevant MHCII alleles well documented (Zamvil et al. 1986; Valli et al. 1993). In recent years numerous structures of these MHCII-peptide complexes and of TCRs bound to them have been solved. The picture that emerges from these studies is that the MBP peptides bind poorly to these MHCII alleles and the complexes are often recognized by the TCRs in unconventional ways. Two examples are particularly revealing.

In one of the mouse models of EAE, animals bearing the IA ${ }^{\mathrm{u}} \mathrm{MHCII}$ allele develop EAE when intentionally immunized with MBP. The important $\mathrm{IA}^{\mathrm{u}}$-presented peptide is at the aminoterminal end of MBP (Zamvil et al. 1986). This peptide binds very poorly to $\mathrm{IA}^{\mathrm{u}}$. The structure of the $\mathrm{IA}^{\mathrm{u}}$ complexed with an altered version of the peptide (He et al. 2002) and of three TCRs from a pathogenic $\mathrm{CD} 4^{+} \mathrm{T}$ cell bound to the complex (Maynard et al. 2005; Feng et al. 2007) show why (Fig. 3A). The structures predict that the natural version of the MBP peptide binds to $\mathrm{IA}^{\mathrm{u}}$ leaving groove positions $\mathrm{p} 1-\mathrm{p} 3$ empty. Furthermore, the lysine that is at $\mathrm{p} 6$ in the MBP peptide is a very poor fit for the hydrophobic $\mathrm{IA}^{\mathrm{u}}$ p6-binding pocket.

In the solved structures, the peptide was altered to make it bind better to $\mathrm{IA}^{\mathrm{u}}$. In interacting with this complex, the TCRs make sparse contact with the peptide, focusing on those amino acids of the altered peptide that are shared with the natural peptide. Therefore, the natural MBP peptide binds poorly to $\mathrm{IA}^{\mathrm{u}}$, because it has a conflicting amino acid at p4 and does not fill the amino-terminal-binding portion of the groove, thus shifting the focus of the TCR away from the usual center of the peptide toward its carboxyl terminus.

The other striking example is in human MS, in which the MBP response is associated with the human MHCII protein, HLA-DR2 and the relevant MBP peptide is from the interior of the protein. As in the mouse case, this peptide binds very poorly to DR2, although it fills the binding groove. However, in the structure of a TCR from an MS patient bound to this ligand (Fig. 3B) (Hahn et al. 2005), the TCR is considerably shifted toward the amino terminus of the peptide making no contact with peptide amino acids from $\mathrm{p} 6$ to the carboxy-terminal end of the
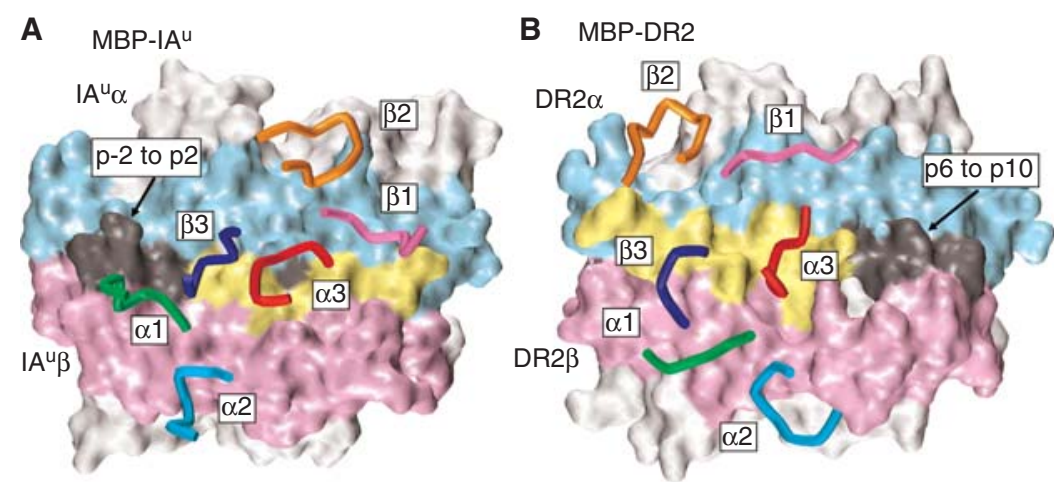

Figure 3. Unconventional MHCII presentation and recognition of MBP to CD4 ${ }^{+}$T-cell autoimmunity. (A) The positions of the TCR CDR loops of a mouse MBP-specific autoreactive CD4 ${ }^{+}$T cell are shown on the surface of $\mathrm{IA}^{\mathrm{u}}$ bound to an MBP mimotope (PDB $\left.1 \mathrm{U} 3 \mathrm{H}\right)$. The CDR loops and surfaces are colored as in Figure 2E, except the portion of the peptide surface formed by amino acids not present in the natural MBP peptide is colored gray. (B) The positions of the TCR CDR loops of a human MBP-specific autoreactive CD4 ${ }^{+} \mathrm{T}$ cell are shown on the surface of HLA-DR2 bound to a different MBP peptide (PDB 1YMM). The CDR loops and surfaces are colored as in Figure 2E, except the portion of the peptide surface that is not within the TCR footprint is colored gray. 
A

$\begin{array}{lrl}\text { A } & \text { Versions of the insulin B9:23 peptide } \\ & 10 & 15\end{array}$

\section{B}

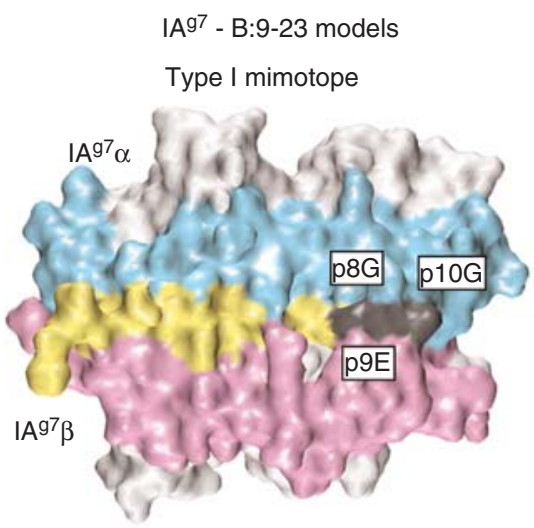

Type II mimotope

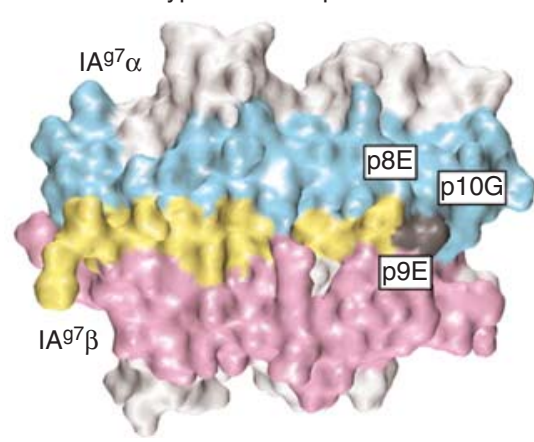

Figure 4. Unconventional $\mathrm{IA}^{\mathrm{g} 7}$ presentation of insulin to $\mathrm{CD} 4^{+} \mathrm{T}$ cells in NOD T1D. (A) The sequence of the insulin B9:23 peptide is shown along with the predicted positions that would occupy the $\mathrm{IA}^{\mathrm{g} 7}$-binding groove were the peptide to bind in register 3 . Also shown are the maximal carboxy-terminal truncations, B:9-20 and B:9:21, tolerated by two types of $\mathrm{B}: 9-23$-reactive NOD diabetogenic $\mathrm{CD} 4^{+} \mathrm{T}$ cells, as well as versions of $\mathrm{B}: 9-23$ that mimic these truncations. (B) Models of the B:9-23 mimotopes for the type I (upper panel) and type II (lower panel) T cells shown in $(A)$ were made based on the solved structure of $\mathrm{IA}^{\mathrm{g} 7}$ bound to a GAD peptide (PDB 1ES0)
The Importance of Neoantigens in Autoimmunity

peptide. Rather the TCR interacts, not only with the amino-terminal peptide amino acids in the groove, but also in a very nonconventional way with those amino acids protruding from the groove out to $\mathrm{p}-4$. We do not know how the MBP peptide for this TCR is processed in situ in MS, but one could predict that truncation from the carboxyl terminus to p6, although weakening peptide binding to DR2, would not disturb interaction of the DR2 plus peptide interaction with the TCR.

The most recent examples of oddly processed and presented self-peptide autoantigens come from the NOD mouse model of T1D (Fig. 4). Most female NOD mice develop spontaneous diabetes at several months of age with $\mathrm{CD} 4^{+}$ T-cell infiltration into the pancreatic islets of Langerhans and specific destruction of the insulin-producing $\beta$ cells. These mice carry the $\mathrm{IA}^{\mathrm{g} 7}$ MHCII allele, which is essential for the development of diabetes (Hattori et al. 1986; Prochazka et al. 1987). There are two well-established protein sources of peptides that stimulate the pathogenic T cells, insulin, and chromogranin A (ChgA) (Daniel et al. 1995; Abiru et al. 2000; Burton et al. 2008; Stadinski et al. $2010 b)$. Both these proteins are very highly expressed in the islet $\beta$-cell secretory granules. Although diabetogenic $\mathrm{CD} 4{ }^{+} \mathrm{T}$-cell clones specific for these proteins have been studied for many years, it is only recently that the nature of the peptide epitopes presented to the pathogenic $\mathrm{T}$ cells has come to light.

In the case of insulin, it has been known for some time that the important $\mathrm{CD} 4^{+} \mathrm{T}$-cell insulin peptides are mostly contained within an insulin $\beta$-chain fragment, B:9-23 (Fig. 4A). However, it has been very hard to determine the relevant $\mathrm{IA}^{\mathrm{g} 7}$-binding register simply from the fragment sequence. Initially much attention was focused on the binding register that placed

using Swiss PDB Viewer. The surface of $\mathrm{IA}^{\mathrm{g} 7}$ is shown colored as in Figure 2E. The surfaces of the portions of the mimotope peptides corresponding to the truncations in $(A)$ are colored yellow. The rest of the peptide surface is colored gray. The p8, p9, and p10 amino acids are labeled. 
the peptide $\mathrm{B}: 21$ glutamic acid in the $\mathrm{IA}^{\mathrm{g} 7} \mathrm{p} 9$ pocket (register 2) (Suri et al. 2002, 2005), because polymorphisms in $\mathrm{IA}^{\mathrm{g} 7}$ uniquely creates a preference for acidic peptide amino acids at $\mathrm{p} 9$, but evidence for other possible binding registers has been reported (Levisetti et al. 2008; Suri et al. 2008; Stadinski et al. 2010c; Crawford et al. 2011). Our laboratory developed methods for trapping peptides in a particular register in the $\mathrm{IA}^{\mathrm{g} 7}$-binding groove, by introducing optimal amino acids at $\mathrm{p} 1$ and $\mathrm{p} 9$ for the corresponding IA ${ }^{\mathrm{g} 7}$ pockets (Stadinski et al. 2010c). Using this approach, we showed that a single binding register (register 3) of the B:9-23 peptide in the IA ${ }^{\mathrm{g} 7}$ groove accounted for the antigen recognized by most, if not all, $\mathrm{B}: 9-23$ reactive NOD CD4 ${ }^{+} \mathrm{T}$ cells. This was an unexpected finding, because in the unaltered $\mathrm{B}: 9-23$ peptide, an arginine would be bound to the $\mathrm{IA}^{\mathrm{g} 7} \mathrm{p} 9$ pocket, leading to very poor binding of the peptide in this register. Perhaps this accounts for the escape of the pathogenic $\mathrm{T}$ cells that react with the insulin peptide in this register from thymic negative selection.

A clue to how this presentation problem for the arginine-containing insulin peptide might be overcome in the pancreas came from the work of the Unanue group (Mohan et al. 2010). They presented data strongly suggesting that the important insulin peptides for $\mathrm{CD} 4^{+} \mathrm{T}$ cells are produced through degradation of insulin in the pancreatic $\beta$ cells themselves rather than the usual APCs. Therefore, these peptides are likely to be loaded into $\mathrm{IA}^{\mathrm{g} 7}$ at the APC cell surface rather than via the conventional endosomal pathway (Fig. 1C). The exact nature of these pancreas-generated peptides is unknown, but another study from the Unanue group (Levisetti et al. 2008) suggested a testable possibility to us. In this study they assessed the responses of a large set of insulin B:9-23-reactive $\mathrm{CD} 4^{+} \mathrm{T}$ cell clones to truncations and mutations of the $\mathrm{B}: 9-23$ peptide presented in vitro by $\mathrm{IA}^{\mathrm{g} 7}$ APCs. One result of this study was to divide the T cells into two types. The response of type II T cells tolerated carboxy-terminal truncation of the peptide back to B:21 and type I T cells tolerated a further truncation to B:20 (Fig. 4A). They interpreted the truncation data as defining the carboxy-terminal p9 amino acid of separate peptide registers, 1 and 2, each defining one of the two types of T cells. Because we had studied some of these same $\mathrm{T}$ cells, we interpreted the truncation data based on register 3 presentation, concluding that, whereas the truncations define two types of T cells, both types recognized truncated peptides bound in register 3 and therefore, the truncated peptides did not fill the IA ${ }^{\mathrm{g} 7}$ peptide-binding groove. Because the responses of both T-cell types survived elimination of the last two amino acids of the B:9-23 peptide, p9R and p10G, this truncation solves the register 3 problem of the $\mathrm{p} 9 \mathrm{R}$ clash with the $\mathrm{IA}^{\mathrm{g} 7} \mathrm{p} 9$ pocket. Type I T cells tolerated the further loss of $\mathrm{p} 8 \mathrm{E}$, but type II T cells did not, suggesting that the interaction with $\mathrm{p} 8 \mathrm{E}$ side chain was required for some TCRs, but was not required or maybe even inhibitory for others.

To test this idea, we constructed versions of the insulin peptide that mimicked these two truncated peptides bound to $\mathrm{IA}^{\mathrm{g} 7}$ in register 3 (Fig. 4A) (Stadinski et al. 2010c; Crawford et al. 2011). In one peptide the $\mathrm{p} 8$ glutamic acid was changed to glycine and the $\mathrm{p} 9$ arginine was changed to glutamic acid, a good fit to the $\mathrm{IA}^{\mathrm{g} 7}$ p9 pocket. In the other peptide only the $\mathrm{p} 9 \mathrm{ar}$ ginine to glutamic acid mutation was made. We reasoned that, when bound in register 3, these mimotope peptides should look very similar to the truncated insulin peptides from the TCR point of view (Fig. 4B). However, these peptides would optimally fill the $\mathrm{IA}^{\mathrm{g} 7}$-binding groove and thus should bind much better to $\mathrm{IA}^{\mathrm{g} 7}$ in this register than the truncated or full-length versions of the wild-type (WT) B:9-23 peptide.

This hypothesis was confirmed when we tested these mimotopes for their ability to stimulate a panel of both types of insulin-reactive NOD T-cell hybridomas (Crawford et al. 2011). As predicted, the mimotope with both the $\mathrm{p} 8$ and $\mathrm{p} 9$ mutations stimulated the type I T cells 10- to 100-fold better than did the WT peptide or mimotope with the p9-only mutation. The mimotope with the p9-only mutation stimulated the type II T cells 10-100-fold better than did the WT peptide or mimotope with both the $\mathrm{p} 8$ and $\mathrm{p} 9$ mutations. Thus, the responses of both types of $\mathrm{T}$ cells were to the insulin peptide 
bound to $\mathrm{IA}^{\mathrm{g} 7}$ in register 3 and were inhibited by the natural p9R, but their TCRs interacted differently with the amino acid at the $\mathrm{p} 8$ position. Type I T cells were inhibited by the natural p8E, whereas type II $\mathrm{T}$ cells required the $\mathrm{p} 8 \mathrm{E}$ for optimal recognition.

These results were used to design two sets of fluorescently labeled register 3 insulin-IA ${ }^{\mathrm{g} 7}$ tetramers, which, among them, bound to the majority of both types of insulin-reactive T-cell hybridomas. These tetramers also detected a large number of insulin-IA ${ }^{\mathrm{g} 7}$-reactive $\mathrm{CD} 4^{+} \mathrm{T}$ cells infiltrating the pancreatic islets of young NOD mice before the onset of overt diabetes (Crawford et al. 2011). Based on the findings, we conclude that the natural insulin peptides that drive T1D in the NOD mouse may well be two truncated versions of the $\mathrm{B}: 9-23$ peptide generated in the pancreas that do not fill the carboxy-terminal end of the $\mathrm{IA}^{\mathrm{g} 7}$-binding groove (Fig. 4B).

A peptide from chromogranin A (ChgA) is our final example of an unusually processed and presented autoantigen in NOD T1D. ChgA is an abundant precursor protein present in the secretory granules of neuroendocrine cells including pancreatic $\beta$ cells (O'Connor 1983; Ehrhart et al. 1986). It is naturally processed in these granules by a furinlike and other proteases into several bioactive peptides. ChgA has only recently been identified as the source of a $\mathrm{CD} 4^{+}$ T-cell autoantigen in NOD mice (Stadinski et al. $2010 \mathrm{~b}$ ), although the potent diabetogenic properties of CD $4^{+}$T cells, which have turned out to be reactive to this antigen, have been studied for many years (Haskins et al. 1988; Burton et al. 2008). A series of mimotope peptides were identified in three different laboratories that when bound to $\mathrm{IA}^{\mathrm{g} 7}$ activated one or more of these T-cell clones (Judkowski et al. 2001; Yoshida et al. 2002; Stadinski et al. 2010b). A common feature of these mimotopes is the five amino acid sequence motif $\mathrm{WX}(\mathrm{KR}) \mathrm{M}(\mathrm{ED})$ in the $\mathrm{p} 5$ to p9 positions of the mimotope sequences, with considerable variability allowed in the $\mathrm{p} 1-\mathrm{p} 4$ amino acids (Fig. 5A).

For many years the pancreatic protein source of the natural epitope for these $\mathrm{T}$ cells could not be identified, despite the fact that ChgA sequence contains the motif in the form of
The Importance of Neoantigens in Autoimmunity

WSRME. Recently, we participated in a study that has offered a solution to this conundrum (Stadinski et al. 2010b). These experiments showed that the antigen for these $\mathrm{T}$ cells was enriched along with ChgA in a partially purified antigen preparation from a $\beta$-cell tumor and was missing in pancreases of $\mathrm{Chg}-\mathrm{A}^{-/-}$mice, establishing ChgA as the source of the antigen. However, a synthetic 10 amino acid ChgA peptide, WEDKRWSRMD, containing the motif failed to activate any of the ChgA-reactive $\mathrm{T}$ cells (Fig. 5A). Unexpectedly, a synthetic version of the natural ChgA cleavage product, WE14 (WSRMDQLAKELTAE), stimulated all of the ChgA clones tested. This was a very surprising result, because this peptide contained the motif at its amino terminus and all of the mimotope studies firmly placed the essential motif in the $\mathrm{p} 5-\mathrm{p} 9$ positions of the $\mathrm{IA}^{\mathrm{g} 7}$-binding groove. Were WE14 to bind in this register, positions up to p5 of the groove would be left empty and the peptide would extend nine amino acids beyond the end of the binding groove (Fig. 5B,C). However, truncation, stimulation, and binding experiments showed that this was indeed the case. Adding back as little as one ChgA amino acid to the amino terminus of WE14 inhibited $\mathrm{IA}^{\mathrm{g} 7}$ binding and $\mathrm{T}$-cell recognition. Moreover, truncation of as little as three amino acids from the carboxy-terminal end of WE14 impaired $\mathrm{IA}^{\mathrm{g} 7}$ binding and T-cell activation. We concluded that WE14 represents another example of a tissue-specific autoantigenic peptide that binds to $\mathrm{IA}^{\mathrm{g} 7}$ usually. Unlike the carboxy-terminal truncations that define the two versions of insulin B:9-23 epitope, the ChgA epitope requires a precise tissue-specific amino-terminal truncation and carboxy-terminal extension.

In humans the functional autoantigens for $\mathrm{CD}^{+}{ }^{+} \mathrm{T}$ cells in T1D have been even harder to work out. Risk of T1D is linked strongly to combinations of the HLA-DR4/DQ8 and DR3/ DQ2 haplotypes (Shiina et al. 2004; Michels and Eisenbarth 2010; Stadinski et al. 2010a). Given the structural similarities between $\mathrm{IA}^{\mathrm{g} 7}$ and DQ2/DQ8, it is tempting to propose that insulin and ChgA might be processed and presented by these MHCII alleles similarly to $\mathrm{IA}^{\mathrm{g} 7}$. However, there is no direct evidence in favor of 
P. Marrack and J.W. Kappler

\begin{tabular}{|c|c|c|}
\hline A & $\begin{array}{l}\text { ChgA mimotopes and peptides } \\
\text { Groove position }(\mathrm{p}) \\
123456789\end{array}$ & $\begin{array}{c}\text { T-cell } \\
\text { stimulatory } \\
\text { activity }\end{array}$ \\
\hline \multirow{5}{*}{$\begin{array}{l}\mathscr{œ} \\
\frac{0}{0} \\
\stackrel{0}{0} \\
\stackrel{\xi}{\Sigma}\end{array}$} & AVRPLWVRME & ++ \\
\hline & QVAPVWVRME & ++ \\
\hline & HIPIWARMD & ++ \\
\hline & HLAIWAKMD & ++ \\
\hline & SRLGLWVRME & ++ \\
\hline \multirow{5}{*}{ 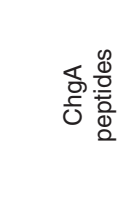 } & (354-362) EDKRWSRMD & - \\
\hline & (354-371) EDKRWSRMDQLAKELTAE & - \\
\hline & \begin{tabular}{l|l} 
(WE14) & WSRMDQLAKELTAE
\end{tabular} & + \\
\hline & WSRMDQLAKEL & \pm \\
\hline & $(358-362)$ & - \\
\hline
\end{tabular}

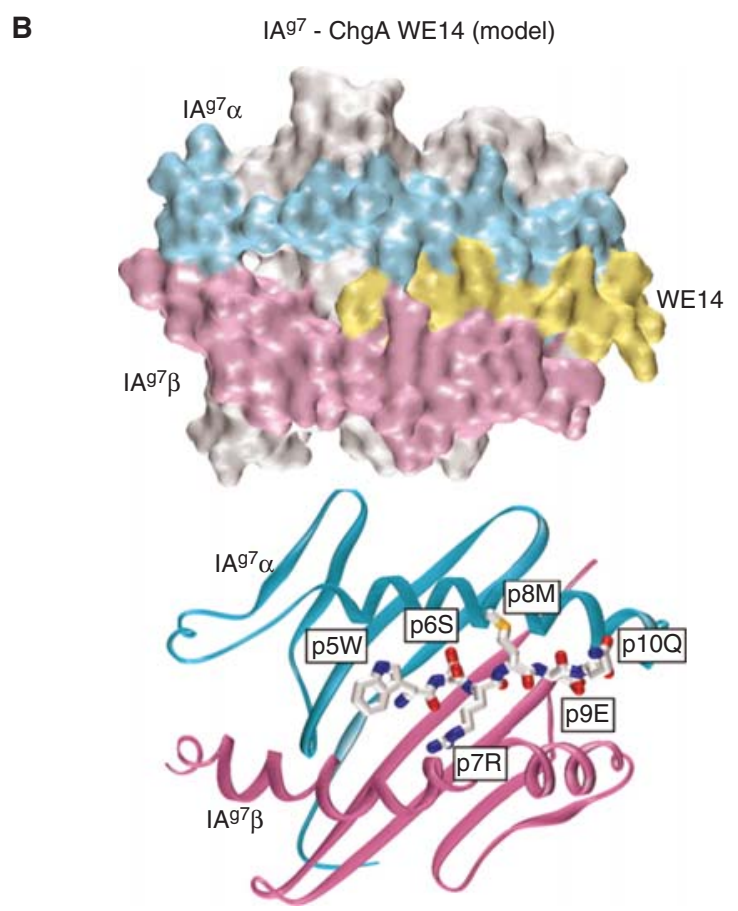

Figure 5. Unconventional $\mathrm{IA}^{\mathrm{g} 7}$ presentation of ChgA to $\mathrm{CD} 4^{+} \mathrm{T}$ cells in NOD T1D. $(A)$ The activity of various ChgA peptides and mimotopes present by $\mathrm{IA}^{\mathrm{g} 7+}$ APC in stimulation ChgA-specific T cells. The peptide mimotopes are representative of those reported in three studies in which they were shown to stimulate strongly one or more ChgA-reactive T-cell clones or hybridomas (Judkowski et al. 2001; Yoshida et al. 2002; Stadinski et al. 2010b). The ChgA peptides are representative of those tested that contained the ChgA WSRMD sequence (Stadinski et al. 2010b). All sequences were aligned based on the WX(RK)M(DE) motif, which is highlighted. The putative positions of the peptide amino acids in the $\mathrm{IA}^{\mathrm{g} 7}$ groove are shown at the top, based on studies with the mimotopes. $(B)$ A model of the ChgAWE14 peptide bound to $\mathrm{IA}^{\mathrm{g} 7}$ was created based on the structures of $\mathrm{IA}^{\mathrm{g} 7}$ bound to a GAD peptide (PDB 1ES0) and $\mathrm{IE}^{\mathrm{k}}$ bound to $\mathrm{pHb}$ (1IEA) using Swiss PDB Viewer. In the upper panel the predicted surface of the complex is shown colored as in Figure 2E. The lower panel shows a ribbon representation of the $\mathrm{IA}^{\mathrm{g} 7} \alpha 1$ (cyan) and 1 (magenta) domains with a wire-frame representation of the first six amino acids of modeled WE14 peptide. The $\mathrm{p} 5-\mathrm{p} 9$ amino acids that make up the shared motif for ChgA-specific $\mathrm{CD}^{+} \mathrm{T}$ cells are labeled as in the p10 glutamine, which is the potential target of transglutaminase, treatment which greatly enhances the stimulatory activity of the WE14 peptide. 
this idea. On the other hand, anti-insulin autoantibodies are nearly universal in human T1D (Zhang et al. 2008) and some data suggest that the $\mathrm{B}: 9-23$ peptide may contain a $\mathrm{CD} 4^{+} \mathrm{T}$-cell epitope (Nagata et al. 2004; Higashide et al. 2006). Alternately, HLA-DR4 presentation of an insulin $\alpha$-chain peptide has been reported (Kent et al. 2005; Mannering et al. 2005), but the details of the MHCII-peptide structure are not known. In humans the WE14 peptide is virtually identical in sequence to that of the mouse and is present in human pancreatic $\beta$ cells, but its activity as a $\mathrm{CD} 4^{+} \mathrm{T}$-cell autoantigen has not been established.

\section{AUTOANTIGENS CREATED BY POSTTRANSLATIONAL MODIFICATIONS IN THE TARGET TISSUE}

In addition to tissue-specific peptide processing and presentation, recent evidence suggests that tissue-specific posttranslational modification of self-peptides may also be important in autoimmunity (Anderton 2004). Although a number of these modifications have been suggested as possibly generating neoantigens for $\mathrm{CD} 4^{+} \mathrm{T}$ cells in autoimmunity and other inflammatory diseases, only a few will be discussed here.

Tissue transglutaminase (TG-2) is an enzyme up-regulated in response to tissue damage during injury and inflammation (Melino and Piacentini 1998; Esposito and Caputo 2005). Its major function appears to be the cross-linking of proteins or peptides via isopeptide bond formation between glutamines and lysines, some suggest leading to stabilization of damaged tissue. However, TG-2 also can convert protein or peptide glutamines to glutamic acids.

This latter reaction has been shown to create neoantigens from the glutamine-rich gliadins that make up wheat and rye gluten. Gliadin peptides modified by TG- 2 are the major target of pathological $\mathrm{CD}^{+}{ }^{+} \mathrm{T}$ cells in celiac disease, a destructive inflammatory bowel syndrome (Sollid 2000; Qiao et al. 2009; Abadie et al. 2011). Although more accurately classified as an allergic inflammatory disease, celiac disease is often grouped with the autoimmune diseases, because of a strong genetic linkage of risk to HLA-DQ2
The Importance of Neoantigens in Autoimmunity

and to a lesser extent with DQ8, the DQ alleles also associated with T1D risk. Also the disease can be thought of as a loss of immunological tolerance to gliadins, foreign proteins that most individuals tolerate without producing an immune response. DQ2 and DQ8 share with $\mathrm{IA}^{\mathrm{g} 7}$ the preference for peptides with an acidic amino acid in the $\mathrm{p} 9$ pocket, but the TG-2 generation of p9 glutamic acid does not explain all of the deaminated gliadin DQ2-presented epitopes identified for the pathogenic $\mathrm{CD} 4^{+} \mathrm{T}$ cells.

Although the activity of TG-2 has been implicated in other inflammatory and autoimmune diseases, the deamidation of gliadin peptides remains the only well-characterized example of a pathologic antigen created by TG-2. However, a preliminary study in NOD T1D showed that TG-2 treatment of the WE14 peptide increased dramatically its potency in activating ChgA-reactive $\mathrm{CD} 4^{+} \mathrm{T}$ cells ( $\mathrm{T}$ Delong and $\mathrm{K}$ Haskins, pers. comm.). In this case it was not the deamidase activity of TG-2 that was important, because synthetically substituting a glutamic acid for the single glutamine in WE14 did not increase the peptide activity, leaving the suggestion that isopeptide bond formation between this glutamine and a lysine on an unknown protein or peptide or some other amine donor might be responsible for the increase in WE14 activity.

The other posttranslational modification that is strongly associated with autoimmunity is the conversion of arginine to citrulline in proteins by members of the peptidylarginine deimidase (PAD) family of enzymes (Vossenaar et al. 2003). Citrulline is naturally found in a number of proteins such as MBP and filaggrin, but in an inflammatory environment other proteins such as vimentin, fibrinogen, enolase, and collagen can become targets of the enzyme. These citrullated proteins have been implicated in RA, where the presence of autoantibodies specific for them has become an important component of diagnosis of the disease.

There is also some evidence that citrullated peptides from these proteins may act as neoantigens for $\mathrm{CD}^{+}{ }^{+} \mathrm{T}$ cells in RA (Hill et al. 2008; Feitsma et al. 2010). The disease is strongly associated with certain suballeles of the human HLA-DR4. In several studies, citrullinated versions 
P. Marrack and J.W. Kappler

of peptides from PAD-targeted proteins have been shown to bind better to DR4. Furthermore, $\mathrm{T}$ cells have been identified in $\mathrm{DR} 4^{+}$humans and DR4 transgenic mice that are specific for these citrullated peptides. Direct evidence that these $\mathrm{T}$ cells play an important role in RA pathology is still lacking, but it seems probable. Because PAD activity is increased during inflammation, a possible role for citrullated proteins in other autoimmune and inflammatory diseases has been suggested.

As mentioned above, very few posttranslational modifications have been thoroughly studied for an important role in the generation of autoimmune $\mathrm{CD} 4^{+}$T-cell epitopes. One worth examining, especially in T1D, is protein glycation, a nonenzymatic addition of reducing sugars such as glucose to free amines, such as those on lysines or protein amino termini (Cho et al. 2007). The glycation reaction begins with the reversible formation of a Schiff base between the sugar aldehyde and the amine. Molecular rearrangements lead to progressively less reversible reactions and the eventual formation of irreversible aggregates of cross-linked proteins called advanced glycation end products (AGEs).

Because of the elevated levels of glucose in the blood, glycation is a serious problem in diabetes, where AGE accumulation is thought to play a role in the cardiovascular damage and other complications associated with the disease (Negre-Salvayre et al. 2009). Glycated hemoglobin levels are often monitored during T1D as an indicator of long-term elevated glucose levels (Soros et al. 2010). Several studies have shown elevated glycation of pancreatic $\beta$ proteins, including insulin, accompanying T1D (McKillop et al. 2002). Although some studies suggest the presence of antibodies to AGE in T1D patients and animals (Turk et al. 2001; Winnock et al. 2001; Nicoloff et al. 2002), as yet no $\mathrm{CD} 4^{+}$T-cell epitopes have been reported to contain a glycated amino acid.

\section{CONCLUDING REMARKS}

Much of the recent autoimmunity literature has focused on the postthymic mechanisms that control activation of self-reactive $\mathrm{T}$ cells, but we make the case here that the primary driver of spontaneous autoimmunity may not be a failure of the normal autoimmunity check points. Instead we suggest that a relatively small number of neopeptides generated uniquely in the target tissue and presented by particular MHCII alleles may be the primary initiators of autoimmune disease. These neopeptides are generated by peripheral tissue-specific proteolysis and/or posttranslational modification. Their production is often enhanced during an inflammatory response. By being loaded into APC extracellularly, they may avoid the binding competition that takes place in the endosomal loading pathway. Their absence in the thymus allows high-affinity self-reactive $\mathrm{CD}^{+} \mathrm{T}$ cells to escape from thymic negative selection. When generated and presented in the right inflammatory context, these antigens may allow these $\mathrm{CD} 4^{+} \mathrm{T}$ cells to slip through the usual peripheral filters in the same way that $T$ cells specific for foreign pathogens do. This is not a new suggestion, but recent structural studies have given some teeth to the notion. As more bona fide peptide-MHCII ligands for pathogenic autoreactive $\mathrm{CD} 4^{+} \mathrm{T}$ cells are structurally characterized, we suspect this idea will gain even more traction.

\section{ACKNOWLEDGMENTS}

Our work is supported by USPHS grants AI18785 and AI-22295.

\section{REFERENCES}

Abadie V, Sollid LM, Barreiro LB, Jabri B. 2011. Integration of genetic and immunological insights into a model of celiac disease pathogenesis. Annu Rev Immunol 29: $493-$ 525.

Abiru N, Wegmann D, Kawasaki E, Gottlieb P, Simone E, Eisenbarth GS. 2000. Dual overlapping peptides recognized by insulin peptide B:9-23 T cell receptor AV13S3 T cell clones of the NOD mouse. J Autoimmun 14: $231-$ 237.

Anderton SM. 2004. Post-translational modifications of self antigens: Implications for autoimmunity. Curr Opin Immunol 16: 753-758.

Bankovich AJ, Girvin AT, Moesta AK, Garcia KC. 2004. Peptide register shifting within the MHC groove: Theory becomes reality. Mol Immunol 40: 1033-1039.

Burton AR, Vincent E, Arnold PY, Lennon GP, Smeltzer M, Li CS, Haskins K, Hutton J, Tisch RM, Sercarz EE, et al. 
2008. On the pathogenicity of autoantigen-specific T-cell receptors. Diabetes 57: 1321-1330.

Busch R, Rinderknecht CH, Roh S, Lee AW, Harding JJ, Burster T, Hornell TM, Mellins ED. 2005. Achieving stability through editing and chaperoning: Regulation of MHC class II peptide binding and expression. Immunol Rev 207: 242-260.

Chambers CA, Allison JP. 1997. Co-stimulation in T cell responses. Curr Opin Immunol 9: 396-404.

Cho SJ, Roman G, Yeboah F, Konishi Y. 2007. The road to advanced glycation end products: A mechanistic perspective. Curr Med Chem 14: 1653-1671.

Crawford F, Kozono H, White J, Marrack P, Kappler J. 1998. Detection of antigen-specific $\mathrm{T}$ cells with multivalent soluble class II MHC covalent peptide complexes. Immunity 8: 675-682.

Crawford F, Stadinski B, Jin N, Michel A, Nakayama M, Pratt P, Marrack P, Eisenbarth G, Kappler J. 2011. The specificity and detection of insulin reactive $\mathrm{CD} 4^{+} \mathrm{T}$ cells in type1 diabetes in the NOD mouse. Proc Natl Acad Sci 108: 16729-16734.

Daniel D, Gill RG, Schloot N, Wegmann D. 1995. Epitope specificity, cytokine production profile and diabetogenic activity of insulin-specific $\mathrm{T}$ cell clones isolated from NOD mice. Eur J Immunol 25: 1056-1062.

Dessen A, Lawrence CM, Cupo S, Zaller DM, Wiley DC. 1997. X-ray crystal structure of HLA-DR4 (DRA*0101, DRB1 ${ }^{*} 0401$ ) complexed with a peptide from human collagen II. Immunity 7: 473-481.

Ehrhart M, Grube D, Bader MF, Aunis D, Gratzl M. 1986. Chromogranin A in the pancreatic islet: Cellular and subcellular distribution. J Histochem Cytochem 34: 16731682.

Erwig LP, Henson PM. 2008. Clearance of apoptotic cells by phagocytes. Cell Death Differ 15: 243-250.

Esposito C, Caputo I. 2005. Mammalian transglutaminases. Identification of substrates as a key to physiological function and physiopathological relevance. FEBS J 272: 615-631.

Falta MT, Fontenot AP, Rosloniec EF, Crawford F, Roark CL, Bill J, Marrack P, Kappler J, Kotzin BL. 2005. Class II major histocompatibility complex-peptide tetramer staining in relation to functional avidity and $\mathrm{T}$ cell receptor diversity in the mouse $\mathrm{CD} 4{ }^{+} \mathrm{T}$ cell response to a rheumatoid arthritis-associated antigen. Arthritis Rheum 52: 1885-1896.

Feitsma AL, van der Voort EI, Franken KL, el Bannoudi H, Elferink BG, Drijfhout JW, Huizinga TW, de Vries RR, Toes RE, Ioan-Facsinay A. 2010. Identification of citrullinated vimentin peptides as T cell epitopes in HLADR4-positive patients with rheumatoid arthritis. Arthritis Rheum 62: 117-125.

Feng D, Bond CJ, Ely LK, Maynard J, Garcia KC. 2007. Structural evidence for a germline-encoded T cell receptor-major histocompatibility complex interaction "codon." Nat Immunol 8: 975-983.

Gay D, Saunders T, Camper S, Weigert M. 1993. Receptor editing: An approach by autoreactive B cells to escape tolerance. J Exp Med 177: 999-1008.

Greenwald RJ, Freeman GJ, Sharpe AH. 2005. The B7 family revisited. Annu Rev Immunol 23: 515-548.
Hahn M, Nicholson MJ, Pyrdol J, Wucherpfennig KW. 2005. Unconventional topology of self peptide-major histocompatibility complex binding by a human autoimmune T cell receptor. Nat Immunol 6: 490-496.

Hammer J, Gallazzi F, Bono E, Karr RW, Guenot J, Valsasnini P, Nagy ZA, Sinigaglia F. 1995. Peptide binding specificity of HLA-DR4 molecules: Correlation with rheumatoid arthritis association. J Exp Med 181: 1847-1855.

Hartley SB, Crosbie J, Brink R, Kantor AB, Basten A, Goodnow CC. 1991. Elimination from peripheral lymphoid tissues of self-reactive B lymphocytes recognizing membrane-bound antigens. Nature 353: 765-769.

Haskins K, Portas M, Bradley B, Wegmann D, Lafferty K. 1988. T-lymphocyte clone specific for pancreatic islet antigen. Diabetes 37: 1444-1448.

Hattori M, Buse JB, Jackson RA, Glimcher L, Dorf ME, Minami M, Makino S, Moriwaki K, Kuzuya H, Imura H, et al. 1986. The NOD mouse: Recessive diabetogenic gene in the major histocompatibility complex. Science 231: 733-735.

He XL, Radu C, Sidney J, Sette A, Ward ES, Garcia KC. 2002. Structural snapshot of aberrant antigen presentation linked to autoimmunity: The immunodominant epitope of MBP complexed with I-Au. Immunity 17: 83-94.

Higashide T, Kawamura T, Nagata M, Kotani R, Kimura K, Hirose M, Inada H, Niihira S, Yamano T. 2006. T cell epitope mapping study with insulin overlapping peptides using ELISPOT assay in Japanese children and adolescents with type 1 diabetes. Pediatr Res 59: 445-450.

Hill JA, Bell DA, Brintnell W, Yue D, Wehrli B, Jevnikar AM, Lee DM, Hueber W, Robinson WH, Cairns E. 2008. Arthritis induced by posttranslationally modified (citrullinated) fibrinogen in DR4-IE transgenic mice. J Exp Med 205: 967-979.

Jensen PE, Weber DA, Thayer WP, Westerman LE, Dao CT. 1999. Peptide exchange in MHC molecules. Immunol Rev 172: $229-238$.

Jones EY. 1997. MHC class I and class II structures. Curr Opin Immunol 9: 75-79.

Josefowicz SZ, Rudensky A. 2009. Control of regulatory T cell lineage commitment and maintenance. Immunity 30 : 616-625.

Judkowski V, Pinilla C, Schroder K, Tucker L, Sarvetnick N, Wilson DB. 2001. Identification of MHC class II-restricted peptide ligands, including a glutamic acid decarboxylase 65 sequence, that stimulate diabetogenic $\mathrm{T}$ cells from transgenic BDC2.5 nonobese diabetic mice. J Immunol 166: 908-917.

Kappler JW, Roehm N, Marrack P. 1987. T cell tolerance by clonal elimination in the thymus. Cell 49: 273-280.

Kent SC, Chen Y, Bregoli L, Clemmings SM, Kenyon NS, Ricordi C, Hering BJ, Hafler DA. 2005. Expanded T cells from pancreatic lymph nodes of type 1 diabetic subjects recognize an insulin epitope. Nature 435: 224-228.

Kisielow P, Bluthmann H, Staerz UD, Steinmetz M, von Boehmer H. 1988. Tolerance in T-cell-receptor transgenic mice involves deletion of nonmature $\mathrm{CD} 4{ }^{+} 8^{+}$thymocytes. Nature 333: 742-746.

Klein L, Jovanovic K. 2011. Regulatory T cell lineage commitment in the thymus. Semin Immunol 23: 401-409. 
Kotzin BL, Falta MT, Crawford F, Rosloniec EF, Bill J, Marrack P, Kappler J. 2000. Use of soluble peptide-DR4 tetramers to detect synovial $\mathrm{T}$ cells specific for cartilage antigens in patients with rheumatoid arthritis. Proc Natl Acad Sci 97: 291-296.

Lee KH, Wucherpfennig KW, Wiley DC. 2001. Structure of a human insulin peptide-HLA-DQ8 complex and susceptibility to type 1 diabetes. Nat Immunol 2: 501-507.

Levisetti MG, Lewis DM, Suri A, Unanue ER. 2008. Weak proinsulin peptide-major histocompatibility complexes are targeted in autoimmune diabetes in mice. Diabetes 57: $1852-1860$.

Lippolis JD, White FM, Marto JA, Luckey CJ, Bullock TN, Shabanowitz J, Hunt DF, Engelhard VH. 2002. Analysis of MHC class II antigen processing by quantitation of peptides that constitute nested sets. J Immunol 169: 50895097.

Mannering SI, Harrison LC, Williamson NA, Morris JS, Thearle DJ, Jensen KP, Kay TW, Rossjohn J, Falk BA, Nepom GT, et al. 2005. The insulin A-chain epitope recognized by human $\mathrm{T}$ cells is posttranslationally modified. J Exp Med 202: 1191-1197.

Marrack P, Scott-Browne JP, Dai S, Gapin L, Kappler JW. 2008. Evolutionarily conserved amino acids that control TCR-MHC interaction. Annu Rev Immunol 26: 171-203.

Mathis D, Benoist C. 2007. A decade of AIRE. Nat Rev Immunol 7: 645-650.

Maynard J, Petersson K, Wilson DH, Adams EJ, Blondelle SE, Boulanger MJ, Wilson DB, Garcia KC. 2005. Structure of an autoimmune $T$ cell receptor complexed with class II peptide-MHC: Insights into MHC bias and antigen specificity. Immunity 22: 81-92.

McFarland BJ, Beeson C. 2002. Binding interactions between peptides and proteins of the class II major histocompatibility complex. Med Res Rev 22: 168-203.

McGargill MA, Derbinski JM, Hogquist KA. 2000. Receptor editing in developing T cells. Nat Immunol 1: 336-341.

McKillop AM, Abdel-Wahab YH, Mooney MH, O'Harte FP, Flatt PR. 2002. Secretion of glycated insulin from pancreatic $\beta$-cells in diabetes represents a novel aspect of $\beta$ cell dysfunction and glucose toxicity. Diabetes Metab 28: 3S61-3S69.

Melino G, Piacentini M. 1998. "Tissue” transglutaminase in cell death: A downstream or a multifunctional upstream effector? FEBS Lett 430: 59-63.

Metzger TC, Anderson MS. 2011. Control of central and peripheral tolerance by Aire. Immunol Rev 241: 89-103.

Michels AW, Eisenbarth GS. 2010. Immunologic endocrine disorders. J Allergy Clin Immunol 125: S226-S237.

Mohan JF, Levisetti MG, Calderon B, Herzog JW, Petzold SJ, Unanue ER. 2010. Unique autoreactive T cells recognize insulin peptides generated within the islets of Langerhans in autoimmune diabetes. Nat Immunol 11: 350-354.

Nagata M, Kotani R, Moriyama H, Yokono K, Roep BO, Peakman M. 2004. Detection of autoreactive T cells in type 1 diabetes using coded autoantigens and an immunoglobulin-free cytokine ELISPOT assay: Report from the fourth immunology of diabetes society T cell workshop. Ann NY Acad Sci 1037: 10-15.
Nakagawa TY, Rudensky AY. 1999. The role of lysosomal proteinases in MHC class II-mediated antigen processing and presentation. Immunol Rev 172: 121-129.

Negre-Salvayre A, Salvayre R, Auge N, Pamplona R, PorteroOtin M. 2009. Hyperglycemia and glycation in diabetic complications. Antioxid Redox Signal 11: 3071-3109.

Nicoloff G, Baydanoff S, Petrova C, Christova P. 2002. Antibodies to advanced glycation end products in children with diabetes mellitus. Vascul Pharmacol 39: 39-45.

Nikoopour E, Sandrock C, Huszarik K, Krougly O, LeeChan E, Masteller EL, Bluestone JA, Singh B. 2011. Cutting edge: Vasostatin-1-derived peptide ChgA29-42 is an antigenic epitope of diabetogenic BDC2.5 T cells in nonobese diabetic mice. J Immunol 186: 3831-3835.

Nimmerjahn F, Milosevic S, Behrends U, Jaffee EM, Pardoll DM, Bornkamm GW, Mautner J. 2003. Major histocompatibility complex class II-restricted presentation of a cytosolic antigen by autophagy. Eur J Immunol 33: $1250-1259$.

O'Connor DT. 1983. Chromogranin: Widespread immunoreactivity in polypeptide hormone producing tissues and in serum. Regul Pept 6: 263-280.

Patil NS, Hall FC, Drover S, Spurrell DR, Bos E, Cope AP, Sonderstrup G, Mellins ED. 2001. Autoantigenic HCgp39 epitopes are presented by the HLA-DM-dependent presentation pathway in human B cells. J Immunol 166: $33-41$.

Prochazka M, Leiter EH, Serreze DV, Coleman DL. 1987. Three recessive loci required for insulin-dependent diabetes in nonobese diabetic mice. Science 237: 286-289.

Qiao SW, Sollid LM, Blumberg RS. 2009. Antigen presentation in celiac disease. Curr Opin Immunol 21: 111-117.

Rammensee H, Bachmann J, Emmerich NP, Bachor OA, Stevanovic S. 1999. SYFPEITHI: Database for MHC ligands and peptide motifs. Immunogenetics 50: 213-219.

Rudolph MG, Stanfield RL, Wilson IA. 2006. How TCRs bind MHCs, peptides, and coreceptors. Annu Rev Immunol 24: 419-466.

Sakaguchi S, ed. 2006. Regulatory T cells. Immunol Rev 212: $5-343$.

Shalev I, Schmelzle M, Robson SC, Levy G. 2011. Making sense of regulatory T cell suppressive function. Semin Immunol 23: 282-292.

Shevach EM. 2009. Mechanisms of foxp $3^{+}$Tregulatory cellmediated suppression. Immunity 30: 636-645.

Shiina T, Inoko H, Kulski JK. 2004. An update of the HLA genomic region, locus information and disease associations: 2004. Tissue Antigens 64: 631-649.

Shimonkevitz R, Colon S, Kappler JW, Marrack P, Grey HM. 1984. Antigen recognition by H-2-restricted T cells. II. A tryptic ovalbumin peptide that substitutes for processed antigen. J Immunol 133: 2067-2074.

Sollid LM. 2000. Molecular basis of celiac disease. Annu Rev Immunol 18: 53-81.

Soros AA, Chalew SA, McCarter RJ, Shepard R, Hempe JM. 2010. Hemoglobin glycation index: A robust measure of hemoglobin Alc bias in pediatric type 1 diabetes patients. Pediatr Diabetes 11: 455-461.

Stadinski B, Kappler J, Eisenbarth GS. 2010a. Molecular targeting of islet autoantigens. Immunity 32: 446-456. 
Stadinski BD, Delong T, Reisdorph N, Reisdorph R, Powell RL, Armstrong M, Piganelli JD, Barbour G, Bradley B, Crawford F, et al. 2010b. Chromogranin A is an autoantigen in type 1 diabetes. Nat Immunol 11: 225-231.

Stadinski BD, Zhang L, Crawford F, Marrack P, Eisenbarth GS, Kappler JW. 2010c. Diabetogenic T cells recognize insulin bound to IAg7 in an unexpected, weakly binding register. Proc Natl Acad Sci 107: 10978-10983.

Suri A, Vidavsky I, van der Drift K, Kanagawa O, Gross ML, Unanue ER. 2002. In APCs, the autologous peptides selected by the diabetogenic I-Ag7 molecule are unique and determined by the amino acid changes in the $\mathrm{P} 9$ pocket. $J$ Immunol 168: 1235-1243.

Suri A, Walters JJ, Gross ML, Unanue ER. 2005. Natural peptides selected by diabetogenic DQ8 and murine IA(g7) molecules show common sequence specificity. $J$ Clin Invest 115: 2268-2276.

Suri A, Levisetti MG, Unanue ER. 2008. Do the peptidebinding properties of diabetogenic class II molecules explain autoreactivity? Curr Opin Immunol 20: 105-110.

Tivol EA, Schweitzer AN, Sharpe AH. 1996. Costimulation and autoimmunity. Curr Opin Immunol 8: 822-830.

Trombetta ES, Mellman I. 2005. Cell biology of antigen processing in vitro and in vivo. Annu Rev Immunol 23: 975-1028

Turk Z, Ljubic S, Turk N, Benko B. 2001. Detection of autoantibodies against advanced glycation endproducts and AGE-immune complexes in serum of patients with diabetes mellitus. Clin Chim Acta 303: 105-115.

Valli A, Sette A, Kappos L, Oseroff C, Sidney J, Miescher G, Hochberger M, Albert ED, Adorini L. 1993. Binding of myelin basic protein peptides to human histocompatibility leukocyte antigen class II molecules and their recognition by $\mathrm{T}$ cells from multiple sclerosis patients. J Clin Invest 91: 616-628.

Vossenaar ER, Zendman AJ, van Venrooij WJ, Pruijn GJ. 2003. PAD, a growing family of citrullinating enzymes:
The Importance of Neoantigens in Autoimmunity

Genes, features and involvement in disease. Bioessays 25: 1106-1118.

Walseng E, Bakke O, Roche PA. 2008. Major histocompatibility complex class II-peptide complexes internalize using a clathrin- and dynamin-independent endocytosis pathway. J Biol Chem 283: 14717-14727.

Winnock F, Christie MR, Batstra MR, Aanstoot HJ, Weets I, Decochez K, Jopart P, Nicolaij D, Gorus FK. 2001. Autoantibodies to a $38-\mathrm{kDa}$ glycosylated islet cell membraneassociated antigen in (pre)type 1 diabetes: Association with IA-2 and islet cell autoantibodies. Diabetes Care 24: $1181-1186$.

Wirnsberger G, Hinterberger M, Klein L. 2011. Regulatory T-cell differentiation versus clonal deletion of autoreactive thymocytes. Immunol Cell Biol 89: 45-53.

Wucherpfennig KW. 2003. MHC-linked susceptibility to type 1 diabetes: A structural perspective. Ann NY Acad Sci 1005: 119-127.

Wucherpfennig KW, Call MJ, Deng L, Mariuzza R. 2009. Structural alterations in peptide-MHC recognition by self-reactive $\mathrm{T}$ cell receptors. Curr Opin Immunol 21: 590-595.

Yoshida K, Martin T, Yamamoto K, Dobbs C, Munz C, Kamikawaji N, Nakano N, Rammensee HG, Sasazuki T, Haskins K, et al. 2002. Evidence for shared recognition of a peptide ligand by a diverse panel of non-obese diabetic mice-derived, islet-specific, diabetogenic $\mathrm{T}$ cell clones. Int Immunol 14: 1439-1447.

Zamvil SS, Mitchell DJ, Moore AC, Kitamura K, Steinman L, Rothbard JB. 1986. T-cell epitope of the autoantigen myelin basic protein that induces encephalomyelitis. Nature 324: $258-260$.

Zhang L, Nakayama M, Eisenbarth GS. 2008. Insulin as an autoantigen in NOD/human diabetes. Curr Opin Immunol 20: $111-118$.

Zhou D, Blum JS. 2004. Presentation of cytosolic antigens via MHC class II molecules. Immunol Res 30: 279-290. 


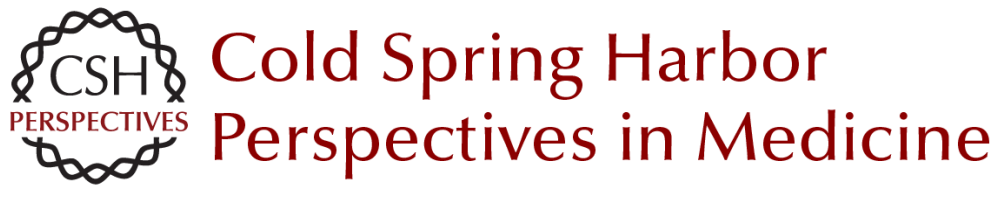

\title{
Do MHCll-Presented Neoantigens Drive Type 1 Diabetes and Other Autoimmune Diseases?
}

\author{
Philippa Marrack and John W. Kappler
}

Cold Spring Harb Perspect Med 2012; doi: 10.1101/cshperspect.a007765 originally published online August 3, 2012

\section{Subject Collection Type I Diabetes}

The Pathogenesis and Natural History of Type 1

Diabetes

Mark A. Atkinson

Do MHCII-Presented Neoantigens Drive Type 1 Diabetes and Other Autoimmune Diseases? Philippa Marrack and John W. Kappler

Clinical Immunologic Interventions for the Treatment of Type 1 Diabetes Lucienne Chatenoud, Katharina Warncke and Anette-G. Ziegler

Update on Islet Transplantation Michael McCall and A.M. James Shapiro

Immunologic and Metabolic Biomarkers of $\beta$-Cell Destruction in the Diagnosis of Type 1 Diabetes Jasmin Lebastchi and Kevan C. Herold

Advancing Animal Models of Human Type 1 Diabetes by Engraftment of Functional Human

Tissues in Immunodeficient Mice Michael A. Brehm, Alvin C. Powers, Leonard D. Shultz, et al.

Breakdown in Peripheral Tolerance in Type 1 Diabetes in Mice and Humans Lukas T. Jeker, Hélène Bour-Jordan and Jeffrey $A$. Bluestone

Antigen-Specific Therapeutic Approaches in Type 1 Diabetes Xavier Clemente-Casares, Sue Tsai, Carol Huang, et al.
Humoral Autoimmunity in Type 1 Diabetes:

Prediction, Significance, and Detection of Distinct Disease Subtypes

Massimo Pietropaolo, Roberto Towns and George S. Eisenbarth

Endoplasmic Reticulum Stress, Pancreatic $\beta$-Cell Degeneration, and Diabetes Feroz R. Papa

Islet Autoantigens: Structure, Function, Localization, and Regulation Peter Arvan, Massimo Pietropaolo, David Ostrov, et al.

Environmental Triggers of Type 1 Diabetes Mikael Knip and Olli Simell

Generating $\beta$ Cells from Stem Cells--The Story So Far Matthias Hebrok

Antigen Targets of Type 1 Diabetes Autoimmunity Bart O. Roep and Mark Peakman

Connecting Type 1 and Type 2 Diabetes through Innate Immunity Justin I. Odegaard and Ajay Chawla

The Hygiene Hypothesis: An Explanation for the Increased Frequency of Insulin-Dependent Diabetes Jean-François Bach and Lucienne Chatenoud

For additional articles in this collection, see http://perspectivesinmedicine.cshlp.org/cgi/collection/ 